\title{
SOR JUANA AND HER LIBRARY WORLD*
}

\author{
Elsa Barberena BLÁSQUEZ**
}

RESUMO

Muitos documentos têm sido elaborados sobre Sor Juana desde a primeira publicação do primeiro volume de Juan Camacho em 1689 na cidade de Madrid. E mais ainda por ocasião de seu aniversário em 1995. Não se sabe exatamente a data de seu nascimento, provavelmente entre 1651 e 1653, falecendo em 1695. As revistas ABSIDE. REVISTA DE CULTURA MEXICANA publicou 25 artigos entre 1941-1973, e CONTEMPORÂNEOS oito, entre 1929 a 1931; o BOLETIN DE LA BIBLIOTECA NACIONAL publicou cinco artigos em 1951 e 1960, mas nenhum destes abordou sua biblioteca. Os seguintes autores têm discutido sua biblioteca: o escritor Ermil Abreu Gómez (1934); Alfonso Méndez Plancarte (1944); o historiador e crítico de arte, Francisco de la Maza (1952); o poeta Octavio Paz (1982); o ex-diretor da Mexican National Library, Ignacio Osorio (1986). Creio que os 4000 volumes de sua biblioteca desempenharam uma parte importante em seus escritos, muito mais que companheiros: objetos de seu mundo. Infelizmente, esta biblioteca, desintegrada por ela mesma ao final de sua vida, é um exemplo de acervos de bibliotecas do Novo Mundo, juntamente com a primeira biblioteca acadêmica desenvolvida na Cidade do México: "La Biblioteca del Colegio de Santa Cruz de Tlaatelolco" (1536). Para saber sobre os títulos de alguns destes livros, cuja existência pode apenas ser conhecido através de suas pinturas de Sor Juana, uma pelo artista mexicano Juan de Miranda, ativo de 1697 a 1711, pertencente à Universidad Nacional Autónoma de México, e a outra pelo pintor mexicano Miguel Cabrera no Museo Nacional de Historia del Castillo de Chapultepec na Cidade do México, nos dá um vislumbre não apenas de sua biblioteca, mas também de seu mundo. Sor Juana com sua beleza, charme, inteligência $e$ habilidade de lidar com as personalidades mais importantes de seu tempo foi considerada uma ponte entre o Novo e o Velho Mundo devido às suas contribuições literárias como mulher, e muito mais ainda como uma mulher Americana do século XVII. Ela é considerada por Alatorre (1995) como o ouro espiritual semelhante ao ouro extraído das minas do Novo Mundo. Metaforicamente, seus escritos são o resultado de seu intelecto e dos conteúdos extraídos de seus livros que representaram o mundo de conhecimento contidos em sua biblioteca.

Palavras-chave: Sor Juana; Literatura mexicana do século XVII

\footnotetext{
(*) Paper presented at the Art Libraries/North America annual conference. San Antonio, Texas, May, 1997.

${ }^{(*)}$ Doctora en Historia de la Universidad Nacional Autónoma de México. Profesora y Asesora del Departamento de Bibliotecología de la División de Estudios Superiores de la Facultad de Filosofía y Letras de la Universidad Nacional Autónoma de México.
} 


\section{ABSTRACT}

There has been numerous documents about Sor Juana since Juan Camacho published his first volume in Madrid in 1689, and more so during 1995, her anniversary. There is no certainty about the date of her birth, it is placed between 1651 and 1653, she died in 1695. The magazines ABSIDE. REVISTA DE CULTURA MEXICANA during the period 1941-1973 published 25 articles, and CONTEMPORANEOS eight articles from 1929 to 1931; the BOLETIN DE LA BIBLIOTECA NACIONAL published five articles in 1951 and 1960, but none of these deal with her library. The following authors have discussed her library: the writer, Ermilo Abreu Gómez(1934); Alfonso Méndez Plancarte (1944); the art historian and critic, Francisco de la Maza (1952); the poet Octavio Paz (1982); the ex-director of the Mexican National Library, Ignacio Osorio (1986). I think that the 4000 volumes of this library played an important part in her writings, and much more than companions: objects of her world. This library unfortunately, disintegrated by her at the end of her life, is an example of library collections and libraries of the New World, together with the first academic library built in Mexico City: "La Biblioteca del Colegio de Santa Cruz de Tlatelolco" (1536).

To know about the titles of some of these books, whose existence can only be seen in two of the paintings of Sor Juana, one by the Mexican artist Juan de Miranda, active from 1697 to 1711, owned by the "Universidad Nacional Autónoma de México", and the other by the Mexican painter, Miguel Cabrera at the "Museo Nacional de Historia del Castillo de Chapultepec" in Mexico City, gives us an idea not only of her library, but of her world. The XVIIC in Mexico City is a baroque century with its four social entities: the Court, the Church, the City and the Convent in which Sor Juana lived. If we take into consideration her writings, there was a fifth entity, the Hispanic literary world. Sor Juana with her beauty, charm, intelligence and ability to deal with the most important personalities of her time was considered a string between the New and the Old Worlds because of her literary contributions as a woman, more so as an American woman of the XVIIC. She is pondered by Alatorre(1995) as the spiritual gold similar to the gold extracted from the New World mines. In a metaphorical way her writings are the result of her intellect and of the contents extracted from the books which represented the world of knowledge contained in her library.

Keywords: Sor Juana; mexican literature, XVIIc.

\section{INTRODUCTION}

There has been numerous documents about Sor Juana since Juan Camacho published his first volume in Madrid in 1689(1), and more so during 1995 , her anniversary. There is no certainty about the date of her birth; it is placed between 1651 and 1653; she died in 1695.

The magazines ABSIDE. REVISTA DE CULTURA MEXICANA during the period 1941-1973 published 25 articles, and CONTEMPORANEOS eight articles from 1929 to 1931; the BOLETIN DE LA BIBLIOTECA NACIONAL published five articles in 1951 and 1960 , but none of these deal with her library.
The following authors have discussed her library: the writer, Ermilo Abreu Gómez (1934)(2),Alfonso Méndez Plancarte (1944)(3); art historian and critic, Francisco de la Maza (1952)(4); the poet Octavio Paz (1982)(5); and the ex-director of the Mexican National Library, Ignacio Osorio (1986)(6).

I think that the 4,000 volumes of this library played an important part in her writings, and much more than companions: objects of her world. This library, unfortunately disintegrated by her at the end of her life, is an example of library collections and libraries of the New World, together with the first academic library built in Mexico City: "La 
Biblioteca del Colegio de Santa Cruz de Tlatelolco"(1536).

To know about the titles of some of these books, whose existence can only been seen in two of the paintings of Sor Juana, one by the Mexican artist, Juan de Miranda, active from 1697 to 1711, owned by the "Universidad Nacional Autónoma de México", and the other by the Mexican painter, Miguel Cabrera at the "Museo Nacional de Historia del Castillo de Chapultepec" in Mexico City, gives us an idea not only of her library, but of her world.

\section{NEW SPAIN}

The XVIIc in Mexico City was a Baroque century with its four social entities: the Court, the Church, the City and the Convent in which Sor Juana lived. If we take into consideration her writings, there was a fifth entity, the Hispanic literary world(7).

The history of Mexico is a juxtaposition of different societies: the Mexican Empire, New Spain, and the Mexican nation. Several elements of the prehispanic world appeared in New Spain: the manners and habits, the familiar and political structures, the legends, handicrafts, myths and beliefs. The Hispanic elements are numerous and stronger: the language, religion and culture.

New Spain was not precolombian, Mexico was not Spain even though it belonged to the Spanish Crown. New Spain could be considered as another kingdom under the Crown just as Castille, Aragón, Navarra or León.

New Spain was a big, prosperous and pacific country. In spite of revolts, hunger, epidemic diseases, and riots, during the XVIc, there was peace during the XVII and the XVIIIc. From the economic point of view New Spain gave more wealth than it received from the Mother Country; the Catholic religion was a new religion in New Spain and an old one in Spain. New Spain during these centuries grew while Spain decayed.

Therefore New Spain was a pluralistic society extremely hierarchical and paternalistic. The land was owned by the religious orders and the secular clergy. At the end of the XVIIc the Church held half of an enormous land, the resources, the products and the consciences of the producers.

The viceroys who ruled as the representatives of the king ofSpain during the life of Sor Juana were: the Marquis de Mancera; Frey Payo de Rivera;the Marquis de la Laguna and Count of Paredes; and the Count de Galve, during nine, six, six and seven years respectively.

Another important element in this society was the viceregal court which had a strong influence in the political and administrative life and became a model of the social life. The Court oversaw the ways in which people dressed, loved, ate and general behaved; it transmitted the European culture and proposed social rules which differed from those that the Church and the University offered. The Court represented a way of living more aesthetic and vital. The Court is the world, the century.

Together with the political and judicial power of the viceroy and the Audience stood the moral and religious authority of the archbishop of Mexico and the bishop of Puebla. The education was in charge of the clergymen in the university.

During the XVIIc the territory of New Spain expanded, the cities grew and their elements were luxury and culture. A rich and sensuous society, and at the same time, pious and superstitious obeyed the royal power and submitted herself to the Church precepts.

New Spain's society had culture, although it was a small group who had the production and communication of the intelectual, artistic and philosophical novelties. Another element was the fusion between the Christian tradition and the classic humanism: the Bible, Ovidio, Saint Augustine, Cicero, Saint Catherine and the sibyl Eritrea.

The literature of New Spain was learned, profoundly religious, in a dogmatic sense, hermetical, aristocrat, written by men and to be read by them: that is why it is really extraordinary that Sor Juana was considered the best writer of New Spain.

It was not possible for a woman to go to the university nor to schools. The only ways to be present in this masculine world were the Court and the Church. An intellectual and aesthetical communication was only possible in the parlour of the convent and the halls of the palaces. 
The architecture is the art where the character and tendencies of a society is manifested. New Spain had its palace, its town-house guild hall and its cathedral, together with the convent, the university and the fortress. The convent and the university were the knowledge centers. The fortress defended the nation from the exterior perils. In a way the convent and the university were also fortresses. The convent occupied an intermediate place between the Court and the Church. The convents were establishments of economic and mercantile activities, but also were centers of an intensive intellectual and worldly life.The XVIIc society in New Spain, according to Octavio Paz, was stronger, more prosperous and civilized than in New England, but was a closed society not only towards the exterior, but to the time to come.

\section{PORTRAIT PAINTING IN NEW SPAIN}

Portrait painting in New Spain could be divided in: civil and religious portraiture. Elisa Vargas Lugo(8) says that there has been very limited research with civil portraits in Mexico. The exhibition at the San Carlos Museum several years ago was related to civil portraiture in New Spain. Among the paintings were two portraits of Sor Juana painted by Juan de Miranda in 1713 and by Miguel Cabrera in 1750.

The element of portrait painting in New Spain which represented the viceregal society is: richness in details, especially in the clothing and jewels depicted. In the case of Sor Juana the clothing varies because in Miranda's portrait the nun is standing holding a quill pen over a page on which the sonnet "Verde embeleso de la vida humana"( Green enravishment of human life) has just been written; her clothing is related to her tense posture. In Cabrera's version the nun is seated ; then the clothing reveals a relaxed body with her hand place on a book printed with two columns of type, open and in the process of being read; according to Luis González Obregón it is the work of Saint Jerome.

In both paintings instead of jewels the details can been seen on the rosaries. Sor Juana holds a rosary in a natural carefree pose in Miranda's painting. In Cabrera's Sor Juana's fingers clasp the rosary forming a closed curve that is full of character according to Héctor Perea (9). The pectorals of the nuns, similar to that of Sor Juana's, were usually made of leather, glass or copper plates, are painted in oils. The pectorals depict the scene of the Annunciation in very similar compositions.

In general the faces of the civil portraits lack in exuberance. It is not the case in Sor Juana portraiture. For Miranda the nun's beauty lays in her worried, ambigous and still young expression. For Cabrera Sor Juana's face is serene and secure; it is the paradoxical image of one who knows almost everything, and for that reason recognizes that she will never know enough. In both faces her beautiful gaze reflects her plural condition as a creole as well as being a nun, a poet, a scholar, a mere reflection of a plural society.

The civil portraits as well as Sor Juana's are surrounded with objects which affirm the attributes of the bodies and a wealth of the mind translated into the social standing of the person portrayed, according to Alberto Ruy Sánchez(10). Sor Juana is surrounded: with books whose spines depict authors such as Saint Jerome, Athanasius Kircher, Theophile Rainaud, Luis de la Puente, Luis de Granada, Juan de Sacrobosco, Juan Pedro Valeriano Bolzani, Jacobo Cansino, Natal Conti, Graciano, Aristotle, Pedro Lombardo, Saint Augustine, Saint Thomas, Virgil, Lucano, Cicero, Marcial, Quintiliano, Silio Italico, Seneca, San Juan de la Cruz, Carlos de Siguenza y Góngora, Galeno, Hipocrates, Duns Escoto.Other objects represented are: a clock, a laboratory flask and the written formula jutting out from it like a flag,and an ink fountain with pens.

In colonial portraiture usually on the table, which varies in its ornamental richness, are often objects that allude to the professional, ecclesiastic, educational or political rank of the subjects. These included, as is the case of Sor Juana's portraits, inkwells, pens, books, miters, birettas or parchment paper. A placard leaning against the table may serve to narrate the life and works of the personage, red velvet drapery is added to impart elegance and color to the entirety(11). Sor Juana's portrait are not as the nun's portraits are; she does not have a lower crown; her portraits are more related to the civil portraiture than to the religious. 
The representation of books is also present in another painting by Cabrera "The Archbishop Francisco Antonio Lorenzano y Butrón”. 1765, and in the painting by José Mariano Farfán de los Godos "Miguel de Berrio y Saldívar, marqués del Jaral de Berrio".1776. Nevertheless none of these personaliities had important libraries of their own.

Although Alberto Ruy Sánchez mentions the importance of what he calls the portrait-poems written by Sor Juana; poetic images that reveal even more about the nature of the society of New Spain, this is not the topic of this paper. The ladies portrayed are Laura, the Marquise of Mancera; Lysi, the Countess of Paredes and Marquise of La Laguna; and Elvira, the Countess of Galve.

\section{THE FIRST LIBRARIES}

The main collections of pre-hispanic Mexico were located at Texcoco and Tenochtitlan, and were kept in temples in the custody of priests. After the Spanish conquest these pre-Columbian libraries or archives were burned, destroyed, or lost. They were called "amoxcalli" (houses of books).

These large collections of hieroglyphs narrated the artistic, scientific, religious and war experiences of pre-Columbian Mexico inhabitants, as well as their traveling,prosperity and magnificence. These collections were true libraries in which a large number of people were entrusted to copy, keep up and arrange the manuscripts on "amate" paper or on strips of venison hide 10 meters long or more, which were rolled or folded accordion wise, putting wood cover at each end so that they resembled books.

It is impossible to talk about a first single library in New Spain. There were:

1. 1534 The first religious library created by Fray Juan de Zumárraga in the cathedral of Mexico. 2. 1536. The first academic library at the "Colegio de Santa Cruz de Tlatelolco". 3. 1553. The first university library of the"Real y Pontificia Universidad ". 5. 1788. The first public library of Mexico of the cathedral.

The history of the first libraries begins with the establishment of a reference library in the cathedral of Mexico in 1534. Two years later the $6^{\text {th }}$ of January of 1536 , the viceroy Antonio de Mendoza, and the friars Juan de Zumárraga, Sebastián Ramírez de Fuenleal, García de Cisneros, Bernardino de Sahagún, Arnaldo de Basacio, and others went to mass at the San Francisco Church, from here went to the quarter of Tlatelolco where the "Colegio Imperial de Santa Cruz" was inaugurated by the viceroy. After the lunch offered by Juan de Zumárraga who donated several volumes from his own book collection the first academic library of the Americas began.

Among the titles were "Logic" by Aristotle, "Opuscula" by Plutarco, works by Esopo, Virgilio, Juvenal, Prudencio, Tito Livio, Flavio, Boecio, Saint Augustine, the "Holy scriptures", vocabularies, catechisms and doctrines.

Tlatelolco the commercial center of Tenochtitlan with its church 'de Santiago" was the site for the new school and seminar. The Imperial "Colegio de Santa Cruz de Tlatelolco" was the first institution for higher education for the Indians in the New World, interested in recovering what was left of the prehispanic 'houses of books". The "Códice Badiano" was elaborated in this school, and other works such as the "Testimonios" of fray Bernardino de Sahagún; in nahuatl "El Arte y Vocabulario" de Molina; the "Psalmodia Christiana" of Sahagún; and the Codices "Matritenses" and "Florentino".

In 1548 Zumárraga's testament said that most of the books of the "Colegio" had to be transferred to the Convent of San Francisco, among them authors such as Dionisio, Hugo de Sancto Claro, Scotus, Lira and Raulin. In 1550 the "Colegio" decayed. The Mexican Council of 1555 prohibited the order of the Indian clergy, and then definitively eliminated the original function of the "Colegio".

The Inquisition was established in New Spain in 1570 , and in 1571 the academic activities of the "Colegio" were practically closed. The inventory of the library revealed in 1572, 61 volumes. Pope Gregory XIII, in 1573, asked to revise all the libraries in New Spain, and all the prohibited books, according to the "Index librorum prohibitorium" printed in Rome in 1559, were confiscated. Among the titles were: the "Bible" with commentaries from Fero and Crisóstomo and the 1553 edition of 
the "Doctrina" by Zumárraga. During the period 1572 to 1574 the library lost several volumes due to the sale performed by the corrupt steward of the "Colegio". At that time the inventory of the library recorded 74 volumes. Another inventory of the library took place in 1582 when books by Vives, Nebrija, Calepino, Ambrossi, Saint Antonii Florentini were missing among others. The final count was 61 volumes, presumably the missing books were with Bernardino de Sahagún and some students. In 1585 a book guardian was hired to solve the problem of book robbery; the censorship of the Inquisition continued.

The first print shop in New Spain was established in 1539. In 1597 a printshop was created at the "Colegio". At the same time about 200 titles were published in New Spain, and books continued arriving from Spain, approximately 782 books were received by the Franciscan order and other persons. A good library would have 1,600 volumes.

The remains of the library stayed at the Convent of Santiago Tlatelolco until 1834. In this year the books were used by the army as mattresses. Later on the books were transferred to the library of the Convent of San Francisco. In here the books were classified as follows: ESC-history, HIS-jurisprudence, JUR-miscellaneous, MIS-moral, MOR-sermons, PRE-secular literature, VAR-commentaries, and EXP-Church fathers. Other letters and numbers were placed on the books to indicate the shelf where there were located. All the ecclesiastical goods were affected by the "Leyes de Reforma". In 1856 the president of Mexico, Ignacio Comonfort nationalized all the goods of the Franciscan order, and in 1859 the Convent of San Francisco together with all its furniture and library were on sale. At this time the inventory of the library of the Convent of San Francisco was 16,477 volumes. The books were dispersed, some went to the National Library, Joaquín García Icazbalceta, the bibliophile, bought some and rebound them, as well as the book-dealer Francisco Abadiano, who later on sold them to the American book collector Adolph Sutro. Now this library belongs to the Library of the State of California in San Francisco. 377 volumes with the fire mark of "Santa Cruz de Tlatelolco", together with some other works printed in Mexico before the year 1601 without the fire mark, plus European 'incunabula', the oldest dated 1485 and four volumes published in 1606 .

This library, which educated the humanists in the way Mesoamerica and the Old World educated, has had many problems such as looses, robbery, censorship, negligence, and finally was sold(12).

SOR JUANA'S LIBRARY

In the XVIIc the political and military powers were Spanish; the economic power was creole and the religious power stood between the two. The dreams and aspirations of the creoles, their need to root themselves in Mexican soil, the fidelity to the Spanish Crown and their Catholic faith could never have been possible without the Jesuits. The awakening of the creole spirit felt in with the emergence of the Jesuits, who relegate the Franciscans and Dominiques, and became the most powerful and influential order of New Spain.

The nationalism of the creoles modified the traditional attitude towards the Indian civilization and provoked a resurrection of the past. The influence of the classic humanism, in particular Plato, was present in this resurrection.

In New Spain there existed a triple conjunction: humanism, Jesuit theology and the aristocrat creole aspirations. Sor Juana was creole.

Carlos Siguenza y Góngora, an ex-Jesuit, born in 1645, friend of Sor Juana was professor of astrology at the "Real y Pontificia Universidad" in 1672. He published yearly meteorological predictions based on his mathematical studies. He tried very hard to know and praise the Indian past. Siguenza y Góngora as well as Sor Juana had a book collection which included not only up to date scientific books, but also a great number of "codices" about the Mexican antiquities. The objetive of this library was to give the creoles information about their past. In his writings the Mexicas were descendants of Neptune. The book collection of almost 1,000 volumes reflects these interests. When Siguenza y Góngora died, his nephew Gabriel López de Siguenza reported that the library was plundered by his friends (13).

Some of these volumes, 28 manuscripts, 170 books, mathematical instruments, and a 
telescope were given, in accordance with his testament, to the Jesuit School of Saint Peter and Saint Paul ("Colegio Máximo de San Pedro y San Pablo") in Mexico City. Among the subject matters of the books were: mathematics, Indian affairs, Spanish and Nahuatl manuscripts, old maps, prehispanic codices, the complete works of the scientist Atanasius Kircher (20 volumes). Unfortunately his library and several of his manuscripts disappeared.

Similar misfortune had the 4,000 volumes(14) of the library of Sor Juana. Her interest in books dates back when she was six or seven years old. By that time she knew how to read and write and asked her mother to take her to the university disguised as a boy. Because this was not possible, she read and studied in her grandfather's library. The book seller Demetrio García discovered an anthology of Latin poets by Octavio della Mirandola(Virgil, Ovid, Horace, Juvenal, Persio, Lucano, Seneca, Boecio, Plauto, Catulo, Marcial, Lucrecio, Propercio, Tibulo), published in Lyon, France in 1590, "Illustrium Poetarum Flores". This book belonged to her grandfather, Pedro Ramírez, and later on to Sor Juana. Ermilo Abreu Gómez examined the book and found in the first page the signature"JHSde Juana Inés de la Cruz, la peor". The same signature appears in the page of the book "Libro de profesiones" which belonged to the convent of Saint Jerome. "Yo, la peor del mundo Juana Inés de la Cruz". In the title page appears also the name Ramírez, her grandfather. Sor Juana said that her grandfather had various types of books, and she read them all; grandfather owned a treasury: his library(15).

In 1656, when Sor Juana was eight years old, beautiful, discreet and elegant, her grandfather died, and then she went to Mexico City to live with the Mata family.When she was young, she learned Latin in twenty lessons. Because of the readings of her grandfather's library, when she arrived in Mexico,everybody was astonished of her knowledge. First she entered the convent of "San José de los Carmelitas", and few months later left it because of the very strict rules. When she was 21 years old she entered the convent of Saint Jerome, named after the saint's. Sor Juana was a frequent reader of the saint's writings.
In relation to Saint Jerome, there is a painting "Saint Jerome in his Studio" painted by Antonello da Messina (1430-79), at the National Gallery of London. Just as Sor Juana, the saint is also surrounded with books, seated, in an armchair in front of a writing desk. The organization in the painting, in the windows, the landscape, the furniture, the animals, the 30 volumes, the written page, the space, the light, the perspective and the body of the saint gives us the elements for a perfect communication between the book and the reader. Antonello painted Saint Jerome, the patron saint of the librarians, few years after Gutenberg printed the first Bible in movable types in 1455. In Miranda's painting Sor Juana is surrounded with 33 books not in order, in Cabrera's with 60 books in perfect order. According to de la Maza the books do not represent the actual book collection of the nun(16).

Nevertheless it is possible to trace the influence of some of these books in Sor Juana's writings. For example: Saint Jerome's epistles written in the IVc affirm the need of women to be learned in order to be good Christians. The interest of Saint Jerome was so great that he offered the Roman lady Paulina "to be his master although I am old and very busy... I will be as honored as Aristotle teaching Alexander, the king of Macedonia". Saint Jerome's teaching method is an attractive teaching method on which sight, touch and hearing develop in complete harmony in order to bring knowledge to the mind; this method is similar to the modern pedagogical system of education.

Another example:Aristotle in the first part of "Politics" affirms the importance of women education and centers it in the concept of virtue. Women as well as men have to be virtuous in order to have a virtuous city. The Greek ideas about women education passed to Rome. The Latin culture is full of examples. The stoics sustained that education has to be the same for men and for women. Roman women having a great culture as Cornelia, Craso's wife, in philosophy, geometry, music and literature; the empress Plotina dedicated herself to the Epicurean philosophy; Julia Dorina who was surrounded with rhetoric mathematicians; Octavia to whom Virgil dedicated the book number six of the "Eneida". 
Plutarco's advice to women to study in a serious way following the Socratic method of combining the study of philosophy with mathematics and astronomy is another example.

The work of Sor Juana "El Sueño", philosophical in essence, is an epistemological work because it searches the causes of human knowledge and its ways of access. The subject of the dream was treated by the Spanish poets before Sor Juana-the analogy of the dream with death. Sor Juana treated the dream as an axis of a philosophical allegory of great amplitude. The originality of the treatment of the poem is that it gives strictly phylosophical preoccupations to an eminently poetic treatment; and all this gives it the aspect of a world encyclopedia. A philosophical ecclecticism which combines the Aristotelic Thomism and the Neoplatonism of Ficino besides the elements of the Kircherian Hermetism to constitute the body of knowledge of her time about the problem of knowledge and divinity.

Sor Juana made an excellent lyric synthesis of the Aristotelic and post-aristotelic theories about the dreams and daydreams. The physiological and psychological notions of the poem are susceptible of giving a scientific explanation of the sleep and dream causes, as well as its link with the intelligence activity of the sleepy body. Other sources of this poem are the Ptolomeo's cosmology, the physics and physiology of Aristotle and Galeno. The night description in the poem comes from Plinio's "Natural History"(17).

In relation to the subject of love, she knew the Neoplatonic theory which has its basis in the theory of the soul that is also the theory of knowledge. Even though in the paintings of Miranda and Cabrera the work of Castiglione "El Cortesano". which was translated into Spanish by Juan Boscán in 1534, is not present, Sor Juana knew about it as well as the "Diálogos de amor" by León Hebreo (18).

\section{CONCLUSION}

My analysis does not go into psychological details as explained by Octavio Paz in his book (19). More so, it goes to the library as an open space. The convent is the equivalent to the library. See "Respuesta a Sor Filotea".
A civilization is a world, a world of objects, and more so a world of names. In a similar way the world of Sor Juana was also a world of objects: books and instruments; the books have names: the authors. The only project of her life was a knowledge conquest. Knowledge is boldness, violence.

Sor Juana's solitude is double: that of the reader and that of the autodidactic woman. The books do not grow old. Her grandfather's library opened for her a different world, different from her home, a world which cannot be entered neither by her mother, and stepfather, nor her sisters. The world of books is an elite world where the material obstacles and the day-to-day contingencies evaporate almost completely. The real true, the books say, are the ideas and the words: reality is the language that signifies them. Sor Juana lived in the house of the language where the ideas cohabit. The house of the ideas is stable, secure, solid. In this changing and ferocious world, there is an inexpugnable place: the library(20).

The life of Sor Juana ended with her personal crisis and that of the society in which she lived, with the unfavorable attitude of the viceroy de Galve and the contradictions of the colonial system imposed to Mexico. Her delusion of the world and knowledge are already present in "El Sueño" where faith replaced knowledge and led her to her worldly farewell.

Sor Juana with her beauty, charm, intelligence and ability to deal with the most important personalities of her time was considered a string between the New and the Old Worlds because of her literary contributions as a woman, more so as an American woman of the XVIIc. She is pondered by Alatorre (21)as the spiritual gold similar to the gold extracted from the New World mines. In a metaphorical way her writings are the result of her intellect and of the contents extracted from the books which represented the world of knowledge contained in her library.

Buxó in his book reconstructs Sor Juana's portrait of intelligence and beauty by means of her poems. I have tried to rebuild her library world through the few titles of the books which appeared in two of her paintings. 
NOTES

(1) Inundación Castálida de la Unica Poetisa Musa Dézima Sor Juana Inés de la Cruz. v.2. Sevilla, 1692; v.3. Madrid,1700.

(2) Abreu Gómez, Ermilo. Sor Juana Inés de la Cruz. Bibliografía y Biblioteca. México, Secretaría de Relaciones Exteriores, 1934. (Monografías Bibliográficas Mexicanas, 29).

(3) Méndez Plancarte, Alfonso. El Universal, September 11,18,25,October 2,9,1944. IN: Crítica de Críticas. México, Las Hojas del Mate, 1982. p.49-149.

(4) Maza, Francisco de la. Primer Retrato de Sor Juana. Historia Mexicana. v.2, n.1p.1-22, July-September, 1952.

(5) Paz, Octavio. Sor Juana Inés de la Cruz o Las Trampas de la Fe. la edición. Barcelona, Seix Barral, 1982. (Biblioteca Breve). p.323-340.

(6) Osorio Romero, Ignacio. Historia de las Bibliotecas Novohispanas. México, Secretaría de Educación Pública. Dirección General de Bibliotecas, 1986. (Historia de las Bibliotecas en México, 1).

(7) Benassy-Berling, Marie-Cecile. El Destino Personal y Literario de Juana Ramírez de Asbaje. IN: Humanismo y Religión de Sor Juana Inés de la Cruz. México, UNAM, 1983. p. $73-86$.

(8) Vargas Lugo, Elisa. Austerity of the Soul. Artesde México, n.25,p.75-77, July-August, 1994

(9) Perea, Héctor. Angulos Oscilantes en el Rostro de Sor Juana. Artes de México, n.25,p.30-37, July-August, 1994.

(10) Ruy Sánchez Lacy, Alberto. Autorretrato de una Sociedad. Editorial. Artes de México, n.25,p.30-37, July-August, 1994.

(11) Vargas Lugo, Elisa. Opus cit.

(12) Mathes, Miguel.Santa Cruz de Tlatelolco:la Primera Biblioteca Académica de las Américas. México, Secretaria de Relaciones Exteriores, 1982. (Archivo Histórico Diplomático Mexicano).

(13) Gómez de Orozco, Federico. Catálogo de la Colección de Manuscritos de Joaquín García Icazbalceta Relativos a la Historia de América. México, SEP, 1927. (Monografías Bibliográficas Mexicanas, 9), p.239.

(14) Calleja, Diego. La Biografía de Sor Juana escrita por Diego Calleja en el Año de 1700. IN: Sor Juana Inés de la Cruz ante la Historia. México,UNAM, 1980. p.149-150.

(15) Paz, Octavio. Opus cit.

(If) Maza, Francisco de la. Opus cit.

(17) Buxó, José Pascual. Sor Juana Inés de la Cruz: Amor y Conocimiento. Prefacio de Alejandro González Actosta. la de. México, UNAM. Instituto de Investigaciones Bibliográficas. Instituto Mexiquense de Cultura, 1996. (Estudios de Cultura Literaria Novohispana, 6).

(18) Buxó, J.P. Opus cit.

(19) Paz, Octavio, Opus cit.

(20) Paz, O. Opus cit.

(21) Alatorre, Antonio. Introducción. Sor Juana Inés de la Cruz. Fama y Obras Póstumas. Edición facsimilar. México, UNAM. Facultad de Filosofia y Letras, 1995.

\section{PAINTINGS OF SOR JUANA}

Puebla Lanborn. Oil painting. Philadelphia Museum of Art. $109 \mathrm{~cm}$. x $79 \mathrm{~cm}$.
Miguel de Herrera. 1732. Banco Nacional de México. $64 \mathrm{~cm} \mathrm{x} 64 \mathrm{~cm}$.

Miguel de Herrera. 1731. Convent of Santa Paula y San Jerónimo, Sevilla. $65 \mathrm{~cm} \times 50 \mathrm{~cm}$.

Litography.La Ilustración Española. Madrid, 36 (39), October 22, 1892.

Juan de Miranda. 1713. Oil painting. Universidad Nacional Autónoma de México.

Miguel de Cabrera. 1750. Oil painting. Museo Nacional de Historia del Castillo de Chapultepec. 2.07 x 1.48.

Andrés de Islas. 1772. Museo Provincial de Tole-do. Now at the Museo de América de Madrid. 105 x $84 \mathrm{~cm}$.

José Chávez. Portrait.

Antonio Ponz. Portrait. Oil painting. Monasterio de los Monjes Jerónimos de El Escorial, España. 1.04 x 84 cm.

Lucas de Valdés. 1692. Drawing.

Engraving.Juan Ignacio de Castorena y Ursua, de.Fama y Obras Póstumas. 1a edición. 1700.

Litography. EI Mosaico Mexicano. Tomo II. México: Ignacio Cumplido, 1837. (Biblioteca de la Universidad Autónoma de San Luis Potosí).

Design.El Renacimiento de México. Tomo II. 1869.

E. Moreau. Litography. Design. Hernández.Crítica de la Literatura de las Ciencias en México desde la Conquista Hasta Nuestros Días. In: Pimentel, Francisco. Poetas. 2. ed. México: Librería de la Enseñanza, 1890.

Engraving.Poetisas Mexicanas de los siglos XVI, XVII, XVIII, XIX.

Source: Tapia Méndez, Aurelio. Carta de Sor Juana Inés de la Cruz a su Confesor. Autodefensa Espiritual. Monterrey, N.L.: Producciones al Voleo El Troquel, S.A., 1992. 253 p.

SOR JUANA'S WORKS

Poetry (lyric, dramatic, allegories, sacred, popular, joyful).

Sacred romances

Spanish stanzas (décimas)

Sonnets (sonetos)

Villancicos and letras. 
Dramatic:

Autos sacramentales: EI Divino Narciso, El Cetro de José, El Mártir del Sacramento

30 loas and comedies in honor of personalities of the Court.

Inundación Castálida. 2 v.

Dramatic profane works:

Los empeños de una casa
Amor es un laberinto

Prose:

Neptuno alegórico

Explicación del arco

Razón de la fábrica alegórica y aplicación de la fábula

Carta Athenagórica

Respuesta a Sor Filotea de la Cruz (carta al obispo de Puebla, Manuel Fernández de Santa Cruz) 